\title{
Arne Kalland: Hval og hvalfangst på Vestlandet 1600-1910
}

Sejersen, Frank

Published in:

Norsk Antropologisk Tidsskrift

Publication date:

2015

Document license:

Ikke-specificeret

Citation for published version (APA):

Sejersen, F. (2015). Arne Kalland: Hval og hvalfangst på Vestlandet 1600-1910. Norsk Antropologisk Tidsskrift, 26(3-4), 312-313. 
Bokanmeldelser

ARNE KALLAND

Hval og hvalfangst på Vestlandet 1600-1910

Oslo: Instituttet for Sammenlignende Kulturforskning/Novus Forlag, 2014, 365 sider. ISBN 978-82-7099-788-6

Arne Kallands mangeårige arbejde med hvalfangstkulturer og natursyn i Japan såvel som i Nordatlanten samt hans ofte meget kritiske analyser af anti-hvalfangstorganisationers kampagner og ideologier præger denne publikation, som skulle blive hans sidste i en lang og produktiv antropologisk karriere. Harald Beyer Broch sørgede for at dette væsentlige bogmanuskript, som lå næsten færdig ved Kallands død i 2012, efterfølgende blev redigeret færdigt og blev udgivet. Kalland tager en interessant kritisk vinkel på norsk hvalfangsthistorie og i et forbilledligt samt omfattende kildearbejde præsenterer han hvalfangstens samfundsmæssige kompleksitet og ændringer i perioden 1600-1910 på Vestlandet. Kalland har valgt denne periode, blandt andet fordi historikere sjældent nævneværdigt har beskæftiget sig med den, og fordi materialets potentialitet ikke har været udforsket systematisk og med en kildekritisk tilgang. En af hans konklusioner er, at hvalfangsten primært var koncentreret få steder, og at den ikke fremstår specielt organiseret. Dermed udfordrer Kalland en udbredt norsk selvforståelse om hvalfangstens historiske betydning og udbredelse i Norge.

Gennem kilder som aviser, retsprotokoller, breve og øjevidneberetninger kommer man tæt på begivenhederne og der tegner sig et interessant billede af en meget famlende hvalfangst hvad angår omfang, teknik, organisering, økonomi og viden. Som i Kallands andre publikationer bliver hans arbejde med hvaler og hvalfangst en antropologisk prisme igennem hvilket, samfund, autoriteter, videnskab, familier og personer træder frem. Regler, uenigheder og konflikter læses af Kalland som sociale kort over lokalsamfundenes historier, hvor økonomiske behov, retsforståelser, aktørpositioner og natursyn bliver synlige. Dermed er bogen også en bog om mennesker og samfund på Vestlandet.

Bogen er ud over en introduktion inddelt i fire dele: 1. Vågehvalfangst med pil og bue, 2. Småhvalfangst med not, 3. Udnyttelse af drivende/strandede hvaler og 4. Opfattelser og viden om hvaler. Hver del har flere kapitler, og Kalland afslutter hvert kapitel med en opsummering af resultater og pointer. I modsætning til andre af Kallands publikationer er denne holdt meget tæt på kilderne, og det analytiske perspektiv ligger snarere i struktureringen af materialet end i en behandling af stoffet. Han anvender således ikke et komplekst og udviklet antropologisk begrebsapparat, men det antropologiske blik ligger som en permanent resonansbund for organiseringen af og den nære fremstilling af og læsning af kilderne. Ligeledes er der tydelige perspektiver hentet fra Science and Technology Studies. Bogen kan også læses som et bidrag til en identitetshistorisk diskussion om hvalfangstens betydning i Norge. Kalland og kilderne viser overbevisende, at den eksisterende forståelse af norsk historisk hvalfangst snarere har rod i norsk nationalchauvinisme end i praksis.

Bogens kapitler har en meget kritisk opmærksomhed på detaljer, og indføringen i hvalfangstens mange facetter og de berørte hvalarter er meget opfattende. Konsekvensen er, at kildernes tvetydigheder og mangler træder tydeligt frem. Det betyder, 
at man som læser også tvinges til at forholde sig analytisk til kilderne. Det er Kallands eksplicitte intention og håb, at andre vil tage tråden op og bruge det materiale, som han har fundet frem, til mere sammenlignende og teoretiserende formål.

Kilderne viser tydeligt, at hvalfangsten i perioden var meget sporadisk og det var formodentlig en af årsagerne til, at befolkningen ikke investerede i redskaber og ikke udviklede en større viden og organisering omkring fangsten. Ligeledes viser kilderne, at arterne var indlejret i forskellige sociotekniske universer. Organiseringen perspektiveres ganske kort til Færøernes grindefangst og i den sammenligning fremstår den norske fangst med økser og andre tilgængelige landbrugsredskaber som alt andet end heroisk, som Kalland også formulerer det. På den anden siden viser bogen også, at den sporadiske og uorganiserede udnyttelse af hvaler alligevel var indskrevet i et gammelt system baseret på gårdenes position, rettigheder, pligter og status, de demografiske forhold, kronens hævd samt fordelingstraditioner fra blandt andet notfiskeriet efter sild. Det er Kallands fortjeneste, at netop denne spænding mellem de uorganiserede elementer og det rammesættende traditionelle system samt mellem det individuelle og fællesskabet kommer frem. Det er især hans arbejde med kilder i retsprotokoller, hvor konflikter over fordeling og betaling for medydelser er beskrevet, at folks engagement og divergerende forståelse af praksis, ret og forventninger træder frem. Bogen skaber i sin meget systematiske og detaljerede fremlægning af udnyttelsen af de forskellige hvalarter, store som små, døde som levende, en række interessant empiriske paradokser. Selvom fangsten ændrede sig fremstår den alligevel statisk, og selvom hvaler blev udnyttet vidste folk overraskende lidt om dem og arbejdede ikke med et etableret artssystem. Kalland konkluderer, at de mest radikale ændringer ses på det kognitive plan, da folks opfattelser og holdninger til hvalerne forandrer sig mærkbart over tid. Især i bogens sidste del koncentrerer Kalland sin opmærksomhed på perceptionen af hvalerne, og han fremskriver et differentieret billede. Interessen for og fascinationen af hvaler spredte sig blandt befolkningen, hvorfor udstillinger og fremvisninger af hvaler og fangst var populære og nærmest blev folkeforlystelser. Interessen udmøntede sig også i et stigende antal protester. Ligeledes viser bogen, hvordan der i slutningen af 1700 tallet voksede en mere empirisk orienteret videnskab frem baseret på undersøgelser af hvalkadavere. Endvidere kom der en øget fokus på hvalernes sociale adfærd samt human aflivning i offentligheden. Den sidste del af bogen om opfattelser og videnskab om hvaler peger på, hvorledes et nyt vidensregime efterhånden blev etableret, og hvilke elementer og netværk det blev konstrueret på baggrund af.

Kallands tidligere omfattende arbejde med hvalfangstens sociale, kulturelle og økonomiske aspekter afspejler sig tydeligt i de opmærksomhedspunkter han etablerer og strukturerer sit arbejde ud fra i denne bog. Beskrivelsen af aktørerne og deres praksisser får både diversitet, forhandlinger og ændringsprocesser til at træde frem. Arne Kallands bog er således ikke kun et bidrag til forståelsen af udnyttelsen af hvaler i Norge, men i lige så høj grad et bidrag til forståelsen af samfundsudviklingen og identitetshistorien. 